Klinička psihologija 9 (2016), 2, 271-292

Pregledni rad - UDK 159.952.3

DOI: $10.21465 / 2016-K P-2-0005$

\title{
LOKUS KONTROLE I TJELESNO ZDRAVLJE
}

\author{
Igor Kardum \\ Odsjek za psihologiju, Filozofski fakultet, Sveučilište u Rijeci \\ Sveučilišna avenija 4, 51000 Rijeka \\ kardum@ffri.hr \\ Jasna Hudek-Knežević \\ Odsjek za psihologiju, Filozofski fakultet, Sveučilište u Rijeci \\ Sveučilišna avenija 4, 51000 Rijeka \\ hudekj@ffri.hr \\ Nada Krapić \\ Odsjek za psihologiju, Filozofski fakultet, Sveučilište u Rijeci \\ Sveučilišna avenija 4, 51000 Rijeka \\ nkrapic@ffri.hr
}

\begin{abstract}
Sažetak
U ovom su radu prikazani efekti lokusa kontrole na tjelesno zdravlje i osnovni mehanizmi putem kojih se ti efekti ostvaruju. U prvom je dijelu rada opisana teorijska osnova lokusa kontrole, prikazani su načini njegova mjerenja i njegov odnos sa sličnim psihologijskim konstruktima, posebno s različitim aspektima percepcije kontrole. Nakon toga navedeni su najvažniji nalazi koji govore o efektima lokusa kontrole na tjelesno zdravlje. Kao osnovni potencijalni mehanizmi putem kojih lokus kontrole može djelovati na tjelesno zdravlje identificirani su njegovo djelovanje na kardiovaskularno i imunološko funkcioniranje te na zdravstvena ponašanja i načine suočavanja sa stresom. Na kraju su navedeni najvažniji teorijski i metodološki problemi prisutni u istraživanjima odnosa između lokusa kontrole i tjelesnog zdravlja.
\end{abstract}

Ključne riječi: lokus kontrole, zdravstveni lokus kontrole, tjelesno zdravlje, zdravstvena ponašanja, suočavanje

Ovaj je članak nastao u okviru znanstvenog projekta pod nazivom "Ličnost, emocije i socijalni procesi kao odrednice zdravstvenih ishoda (13.04.1.2.01)", koji financira Sveučilište u Rijeci. 


\section{LOKUS KONTROLE I NJEGOVO MJERENJE}

Internalna spram eksternalne kontrole potkrepljenja, često nazvana i lokusom kontrole, jedna je od najčešće istraživanih varijabli u psihologiji i drugim društvenim znanostima (Rotter, 1990). Ova je dimenzija ličnosti proizašla iz Rotterove teorije socijalnog učenja, a označava generalizirano očekivanje o odrednicama životnih događaja kao što su nagrade i kazne.

Rotterova se teorija temelji na pretpostavci da ponašanje pojedinca nije determinirano samo prirodom ili značenjem ciljeva ili potkrepljenja nego i njegovim očekivanjem da će se ti ciljevi ostvariti. Očekivanje predstavlja subjektivnu vjerojatnost pojedinca da je potkrepljenje (ostvarenje cilja) funkcija njegova specifičnog ponašanja u određenoj situaciji. Ono je rezultat prethodnih potkrepljenja koje ili smanjuju ili povećavaju očekivanje da će neko ponašanje i dalje dovoditi do pozitivnih ishoda. U onoj mjeri u kojoj se situacije percipiraju kao međusobno slične pojavljuje se i generalizacija očekivanja. Zbog toga je očekivanje u nekoj pojedinačnoj situaciji funkcija prošlih potkrepljenja u toj situaciji i generaliziranog očekivanja nastalog na osnovi iskustva u sličnim situacijama.

Teorija socijalnog učenja također podrazumijeva da pojedinci grupiraju različite situacije u određene klase ili kategorije. Te se kategorije stvaraju na temelju bitnih zajedničkih obilježja situacija. Jedna od takvih kategorija ili dimenzija situacija odnosi se na to je li potkrepljenje posljedica vlastite aktivnosti ili je rezultat sreće ili drugih nekontrolabilnih vanjskih faktora. Dakle, situacije se mogu grupirati u skladu s percipiranim uzrokom potkrepljenja ili lokusom kontrole.

Internalna spram eksternalne kontrole odnosi se na stupanj u kojem pojedinac očekuje da je potkrepljenje ili ishod njegova ponašanja rezultat njegovih karakteristika naspram stupnja očekivanja da je potkrepljenje ili ishod funkcija slučajnosti, sreće, sudbine ili da je pod kontrolom moćnih drugih osoba (Rotter, 1990). Osobe s visokim internalnim lokusom kontrole očekuju da potkrepljenja ili ishodi u velikoj mjeri ovise o njihovim vlastitim naporima. Te su osobe uvjerene u vlastitu sposobnost kontrole nad svojim životnim događajima. Drugi ekstrem čine osobe s visokim eksternalnim lokusom, koje očekuju da potkrepljenja ili ishodi u velikoj mjeri ovise o sreći, sudbini, slučajnosti i ostalim eksternalnim faktorima. Te se osobe osjećaju relativno bespomoćno u pogledu vlastitih životnih događaja jer vjeruju da oni nisu pod njihovom kontrolom. Lokus kontrole ne odnosi se na specifična očekivanja vezana uz specifične ishode u specifičnim situacijama, nego predstavlja generalizirano očekivanje o tome jesu li naša ponašanja instrumentalna za postizanje ciljeva bez obzira na prirodu ciljeva ili potkrepljenja. Međutim, lokus kontrole utječe na specifično očekivanje cilja u svakoj pojedinoj situaciji, pri čemu veličina tog utjecaja ovisi o novosti i neodređenosti situacije kao i o veličini potkrepljenja koje je pojedinac prije dobio u toj situaciji (Weiner, 1992).

Za mjerenje individualnih razlika u sklonosti da se događaji percipiraju kao internalno ili eksternalno kontrolirani Rotter je razvio Skalu internalne-eksternalne 
kontrole (Internal-External Control Scale) koja se sastoji od 29 čestica prisilnog izbora. Primjer jedne čestice izgleda ovako: a) Mnoge poteškoće u životu djelomično su posljedica loše sreće; b) Ljudske nevolje posljedica su njihovih pogrešaka. Izbor prve tvrdnje govori o eksternalnom, a druge o internalnom lokusu kontrole. Iako autori navode da je ova skala unidimenzionalna, brojna su kasnija istraživanja dobivala rezultate koji su upućivali na njenu višedimenzionalnost, izlučujući od 2 do 5 faktora, pri čemu eksternalni lokus kontrole češće pokazuje složeniju strukturu nego internalni (Furnham, 2009; Furham i Steele, 1993).

Nakon pojave ove skale konstruirano je još nekoliko desetaka različitih skala za mjerenje lokusa kontrole, a najvažniji poticaji za njihovu konstrukciju bili su, s jedne strane, razvoj multidimenzionalnih skala lokusa kontrole, a, s druge strane, razvoj skala za primjenu u specifičnim uvjetima (Furnham, 2009). Uz Rotterovu, vjerojatno najčešće korišten mjerni instrument za mjerenje generaliziranog lokusa kontrole je Skala multidimenzionalnog lokusa kontrole koju je konstruirao Levenson (1974). To je trofaktorska skala, koja uz internalni mjeri i dva aspekta eksternalnog lokusa kontrole - moćni drugi i slučajnost.

Rotterova skala lokusa kontrole konstruirana je za mjerenje generaliziranih očekivanja i zbog toga nije najprikladnija za predviđanje specifičnih ponašanja u različitim situacijama. Da bi se poboljšalo predviđanje ponašanja i u specifičnim situacijama, razvijene su i brojne specifične mjere lokusa kontrole za predviđanje specifičnih ponašanja u različitim domenama, kao što su npr. skale zdravstvenog, radnog i akademskog lokusa kontrole, kao i skale namijenjene različitim dobnim skupinama. Od skala zdravstvenog lokusa kontrole jedna od najčešće korištenih je Multidimenzionalna skala zdravstvenog lokusa kontrole (MHLC; Wallston, Wallston i DeVellis, 1978), koja, po uzoru na Levensonovu skalu, mjeri tri aspekta zdravstvenog lokusa kontrole; internalni zdravstveni lokus kontrole, zdravstveni lokus pod kontrolom moćnih drugih te slučajnosti. Zajednička faktorska analiza ove skale i brojnih drugih konstrukata ličnosti koji su povezani sa zdravstvenim ishodima pokazuje da je internalni lokus kontrole najviše povezan s mjerama samoefikasnosti, optimizma i nekih aspekata čvrstoće ličnosti (kontrole i predanosti) koje zajedno čine faktor višeg reda nazvan optimistična kontrola, dok su zdravstveni lokus pod kontrolom moćnih drugih i slučajnosti dio faktora koji je nazvan pasivnost. Treba napomenuti i da su sve tri komponente zdravstvenog lokusa kontrole relativno nezavisne od širokih crta ličnosti kao što su dimenzije petofaktorskog modela ličnosti (Kardum i Hudek-Knežević, 2012).

Konstruirane su i brojne specifične skale zdravstvenog lokusa kontrole koje se odnose na specifična očekivanja vezana uz pojedinu vrstu zdravstvenih problema, kao što su npr. lokus kontrole dentalnog zdravlja, lokus kontrole srčanih bolesti, lokus kontrole tjelesne težine, dijabetesa, karcinoma, hipertenzije, pušenja, porođaja, zdravlja fetusa itd. (Furnham, 2009; Furnham i Steele, 1993; Haslam i Lawrence, 2004; Stevens, Hamilton i Wallston, 2011). Međutim, vrlo je malo istraživanja pokazalo da su specifične mjera lokusa kontrole bolje za predviđanje specifičnih 
ponašanja od skala koje mjere generalizirani lokus kontrole. Osim toga, za ispitivanje njihove konkurentne valjanosti i dalje se najčešće koristi originalna Rotterova skala, koja se u gotovo svim slučajevima visoko preklapa s različitim faktorima lokusa kontrole. Furnham i Steele (1993) smatraju da su jedine prednosti novokonstruiranih mjera specifičnih lokusa kontrole u njihovoj boljoj očiglednoj valjanosti i lakšoj interpretaciji. Zbog toga bi prije konstrukcije novih mjernih instrumenata najprije trebalo riješiti neke važne teorijske i praktične probleme vezane uz konceptualizaciju lokusa kontrole. Tako npr. Weiner (1992) ističe sljedeća tri problema vezana uz konstrukt internalnost-eksternalnost. Prvo, "sreća" se može percipirati i kao internalna (npr. "Ja sam osoba koja ima sreće") i kao eksternalna, tj. kao slučajni događaj (npr. "Imao sam sreće"), ovisno o specifičnom značenju čestica upitnika za svakog pojedinca. Drugo, i internalni i eksternalni lokus kontrole mogu biti stabilni tokom vremena (npr. sposobnosti, težina zadatka) ili nestabilni (npr. uloženi napor, sreća, umor). Treće, navedeni uzroci nekog događaja ne variraju samo na dimenziji internalnost-eksternalnost nego i na dimenziji kontrolabilnosti. Tako je npr. sposobnost ne samo stabilna nego i nekontrolabilna, dok je umor nestabilan, ali i kontrolabilan. Brewin i Shapiro (1984) kao dodatni problem navode da je teško odrediti što zapravo znači ukupan skor koji ispitanici postižu na skali lokusa kontrole ako ne razlikujemo pozitivne i negativne ishode, dok Furnham (2009) navodi da nije jasno odnosi li se lokus kontrole na atribucije o prošlim uzrocima, na očekivanja o budućim događajima ili pak obje vrste kognicija imaju različitu ulogu u različitim kontekstima. Pri konstrukciji novijih mjera lokusa kontrole navedeni se problemi vrlo rijetko rješavaju, pa je zbog toga prije konstrukcije novih mjera nužno učiniti napredak u teorijskoj konceptualizaciji lokusa kontrole (Furnham, 2009).

\section{LOKUS KONTROLE I SRODNI KONSTRUKTI}

Unutar psihologije ličnosti i zdravstvene psihologije razvijeni su brojni konstrukti koji su više ili manje slični lokusu kontrole. Poznato je da je internalnosteksternalnost jedna od triju dimenzija kauzalne atribucije. Nadalje, čvrstoća ličnosti (hardiness), konstrukt koji se također vrlo često koristi $u$ istraživanjima efekata ličnosti na zdravstvene ishode kao jednu od triju komponenti sadrži i uvjerenje pojedinca da može kontrolirati događaje u svom životu (Kobasa, 1982). Lokusu kontrole srodni su i konstrukti koji se temelje na percepciji vlastite kompetentnosti, kao što su samoefikasnost (Bandura, 1982), motivacija za kompetentnošću (Koestner i McClelland, 1990) i sl. Osim toga, razvijeni su i brojni konstrukti kao što su npr. kontrolabilnost, želja za kontrolom i osjećaj kontrole koji se kao i lokus kontrole odnose na percepciju kontrole nad nekim aspektom vlastitog ponašanja ili događaja u okolini. Neki autori (npr. Syme, 1989) čak pretpostavljaju da i neki drugi konstrukti povezani s većom incidencijom i prevalencijom bolesti nezavisno od ostalih poznatih rizičnih faktora, kao što su socijalna podrška, A-tip ponašanja 
i stresni događaji također odražavaju različite aspekte ili manifestacije kontrole ili odsutnosti kontrole. Percepciju kontrole ili srodne konstrukte nalazimo i u teorijama koje nastoje objasniti različite aspekte ponašanja, kao što su npr. transakcijska teorija stresa i suočavanja (Lazarus i Folkman, 2004), teorija samoregulacije ponašanja (Carver i Scheier, 1981) i teorija kognitivne adaptacije (Taylor, 1983).

Iako se može pretpostaviti da se navedeni konstrukti znatno preklapaju, njihovi su nam točni međusobni odnosi za sada uglavnom nepoznati, što znatno otežava integraciju istraživačkih rezultata. Isto tako nedovoljno su nam poznate i specifičnosti ovih konstrukata. Naime, različiti konstrukti naglašavaju djelomično različite aspekte kontrole, pa se može pretpostaviti da je svaki od njih važan u objašnjenju različitih zdravstvenih ishoda ili u različitim fazama odnosa između stresa i bolesti (vidi opširnije u Kardum i Hudek-Knežević, 2009; 2012a; 2016). Parkes (1989) navodi da u literaturi prevladavaju tri pogleda na koncept kontrole. Prvi, koji najčešće nalazimo u istraživanjima iz područja psihologije rada i organizacijske psihologije kontrolu promatra kao objektivnu karakteristiku situacije, pri čemu se kontrola obično shvaća kao stupanj efikasnog utjecaja na događaje, stvari i osobe. Drugi pogled kontrolu shvaća kao subjektivnu, tj. kao percepciju pojedinca o tome koliko može kontrolirati vlastita stanja, ponašanje i okolinu. Tako shvaćena kontrola odražava uvjerenja, stavove i očekivanja pojedinca, a djelomično i objektivne karakteristike situacije. Treći je pogled na kontrolu onaj koji proizlazi iz Rotterove teorije, u kojoj se ona promatra kao dimenzija ličnosti, odnosno kao generalizirano uvjerenje pojedinca o tome jesu li važni ishodi determinirani internalnim ili eksternalnim faktorima.

Neki autori pokušavaju integrirati konstrukte koji se odnose na različite aspekte kontrole s ciljem povećanja prediktivne valjanosti. Tako npr. Wallston (1989) predlaže konstrukt percipirane kompetentnosti koji bi uključivao dva aspekta kontrole, kontrolu nad vlastitim ponašanjem i kontrolu nad ishodima. Dok lokus kontrole odražava stupanj percipirane kontrole nad ishodima, percepcija samoefikasnosti, koja također proizlazi iz teorije socijalnog učenja, odražava kontrolu nad vlastitim ponašanjem. On pretpostavlja da se efekti samoefikasnosti na potencijal za ponašanje modificiraju u skladu s lokusom kontrole. Naime, samoefikasnost predviđa ponašanje samo kod internalnog lokusa kontrole. Ako netko ne vjeruje da njegovo ponašanje utječe na ishode, tj. ako ima eksternalni lokus kontrole, tada je svejedno kakva je njegova percepcija kontrole nad vlastitim ponašanjem, odnosno percipirana samoefikasnost. Dakle, za percipiranu samoefikasnost nužan je internalni lokus kontrole, dok internalni lokus kontrole ne mora nužno biti povezan s visokom samoefikasnošću. Rezultati njegovih, kao i istraživanja drugih autora (Shelly i Pakenham, 2007) pokazuju da interakcija samoefikasnosti i lokusa kontrole ima bolju prediktivnu valjanost nego svaka od tih dviju varijabli zasebno. Za mjerenje ovih dvaju aspekata kontrole konstruirao je skalu percipirane kompetentnosti, pri čemu kompetentnost uključuje i kontrolu nad vlastitim ponašanjem i njegovim ishodima. 
Ovaj nam primjer govori ne samo o važnosti različitih aspekata kontrole nego nam pokazuje i jedan od mogućih načina njihove integracije.

U svakom slučaju činjenica da je razvijeno mnoštvo srodnih konstrukata govori o važnosti koncepta kontrole, pogotovo kada se radi o stresu i zdravstvenim ishodima. Zbog toga je koncept kontrole potencijalno vrlo koristan za integraciju velikog broja različitih i naizgled nepovezanih i nezavisnih rezultata istraživanja.

\section{LOKUS KONTROLE I ZDRAVSTVENI ISHODI}

Dosadašnja istraživanja pokazuju da lokus kontrole ima značajne efekte na različite zdravstvene ishode te da je internalni lokus uglavnom povezan s pozitivnim, a eksternalni s negativnim zdravstvenim ishodima. Osobe s internalnim lokusom kontrole općenito su zdravije i rjeđe obolijevaju od akutnih i kroničnih bolesti, a i onda kada se razbole bolest im traje kraće nego kod osoba s ekternalnim lokusom (Baker, Buchanan i Corso, 2008; Chambers i sur., 2013; Reeh, Bryan i Cairns, 1988).

Ako se zdravlje operacionalizira kao samoprocjena subjektivnih tjelesnih simptoma, istraživanja uglavnom konzistentno pokazuju da je internalni lokus kontrole povezan s manjim brojem i manjim intenzitetom doživljenih tjelesnih simptoma (Hudek-Knežević i Kardum, 2009; Kiviruusu, Huurre, Haukkala i Aro, 2013; Perrig-Chiello, Perrig i Stähelin, 1999; Simoni i Ng, 2002; Van der Voort, Luis i Hamilton, 1997). Ovakvi se rezultati najčešće objašnjavaju zaštitnim djelovanjem internalnog lokusa kontrole od negativnih efekata stresa (Roddenberry i Renk, 2010; Siman-Tov i Kaniel, 2011). Međutim, već je Rotter predvidio da odnos između lokusa kontrole i zdravstvenih ishoda nije linearan, odnosno da i osobe s visokim internalnim lokusom kontrole u određenim uvjetima mogu biti podložnije negativnom djelovanju stresa u odnosu na osobe s umjerenim internalnim lokusom. To se najčešće događa u stresnim situacijama koje se objektivno ne mogu kontrolirati i koje kod osoba s vrlo visokom internalnošću dovode do povećanog doživljaja stresa. Tome u prilog govore i istraživanja o odnosu lokusa kontrole i psihološke prilagodbe pacijenata oboljelih od kroničnih i/ili za život prijetećih bolesti. Naime, u nekim je istraživanjima nađeno da je psihološka prilagodba bolja kod pacijenata s eksternalnim (Burish, Carey, Wallston, Stein, Jamison i Lyles, 1984), u nekim da je ona bolja kod pacijenata s internalnim lokusom kontrole (Poll i Kaplan De-Nour, 1980), a u nekima nije nađena nikakva povezanost između lokusa kontrole i psihološke prilagodbe (Fowers, 1994). Zbog tako raznovrsnih rezultata pretpostavlja se da je veza između lokusa kontrole i psihološke prilagodbe moderirana kontekstualnim varijablama, tj. da se treba usmjeriti na interakcijske, a ne glavne efekte lokusa kontrole. Kada je kontekstualna varijabla kontrolabilnost stresne situacije, tada istraživanja pokazuju da su efekti lokusa kontrole na psihološku prilagodbu najbolji ako postoji sukladnost između lokusa kontrole i realne mogućnosti kontrole stresne 
situacije (Folkman, 1984; Andrykowski i Brady, 1994). Druga važna kontekstualna varijabla koja može moderirati efekt lokusa kontrole na psihološku prilagodbu je razina prijetnje koju izaziva bolest. Folkman (1984) smatra da se važnost internalnog lokusa za psihološku prilagodbu povećava u skladu s povećanom procjenom prijetnje. Dakle, dok kontrolabilnost moderira efekte lokusa kontrole na prilagodbu tako što izaziva veći doživljaj stresa onda kada se lokus kontrole ne poklapa s realnom mogućnošću kontrole situacije, procjena prijetnje dovodi do toga da će ta interakcija biti najizrazitija kod vrlo opasnih bolesti. Istraživanja izvedena na pacijentima na hemodijalizi (Christensen, Turner, Smith, Holman i Gregory, 1991), pacijentima oboljelima od karcinoma (Andrykowski i Brady, 1994) i dijabetičarima ovisnima o inzulinu (Helgeson i Franzen, 1998) potvrđuju da kontrolabilnost i prijetnja upravo na ovakav način moderiraju efekte lokusa kontrole na psihološku prilagodbu.

Važan aspekt lokusa kontrole, pogotovo u kontekstu psihološke prilagodbe na bolest i traumatska iskustva odnosi se na njegovu vremensku usmjerenost. Naime, percepcija kontrole nad ishodima može se odnositi na prošle, sadašnje i buduće događaje (Frazier i Schauben, 1994). Istraživanja pokazuju da pojedinci koji su uglavnom usmjereni na prošle i sadašnje događaje pokazuju slabiji oporavak nakon stresnih i traumatskih doživljaja nego pojedinci koji su usmjereni na percepciju kontrole budućih događaja (Alexander i Wells, 1991).

Treba napomenuti da postoje i uvjeti u kojima eksternalni lokus kontrole može dovesti do bolje psihološke adaptacije. Istraživanja u kojima se pojedine komponente lokusa kontrole tretiraju kao zavisne varijable pokazuju da kod kroničnih bolesnika, kod bolesnika koji su duže vrijeme hospitalizirani i kod starijih osoba koje imaju češći kontakt s medicinskim osobljem ili su češće hospitalizirani dolazi do povećanja eksternalnog lokusa, pogotovo na dimenziji moćni drugi (Perrig-Chiello i sur., 1999). Pretpostavlja se da je ta promjena adaptivan odgovor u situaciji kada je pacijent u velikoj mjeri ovisan o drugima, pri čemu zdravstveno osoblje također preferira i vjerojatno potkrepljuje takvu orijentaciju (Hamdan-Mansour, Marmash, Alayyan i Hyarat, 2014). U bolničkim uvjetima percepcija da je naše zdravlje kontrolirano od strane moćnih drugih dovodi do veće pažnje medicinskog osoblja i većeg broja socijalnih kontakata i općenito ima bolji efekt na psihološku adaptaciju bolesnika nego internalni lokus kontrole (Burns i Mahalik, 2006). Međutim, kada se radi o neizlječivim bolestima ili kada pojedinac na temelju prethodnih tretmana zaključi da zdravstveno osoblje ima slabu kontrolu nad njegovom bolešću, tada eksternalni lokus povećava doživljaj stresa (Wallston, 1989).

Kada se radi o objektivnim zdravstvenim ishodima, istraživanja pokazuju da je eksternalnost povezana s povećanim (Dalgard i Håheim, 1998), a internalnost sa smanjenim mortalitetom (Rodin i Langer, 1977). Također, eksternalni lokus kontrole djelomično posreduje efekte niskog socioekonomskog statusa na viši mortalitet (Bosma, Schrijvers i Mackenbach, 1999). Internalni lokus kontrole povezan je s boljim dugotrajnim zdravstvenim ishodima nakon ozljede leđne moždine (Krause, Stanwyck i Maides, 1998), moždanog udara (Johnston, Morrison, MacWal- 
ter i Patridge, 1999), infarkta miokarda (Hoffmann, Pfiffner, Hornung i Niederhauser, 1995), dijabetesa tipa 2 (O’Hea i sur., 2009) i ugradnje umjetnog koljena (Kendell, Saxby, Farrow i Niasby, 2001), kao i s višim indeksima zdravlja zubi (Potdar, Lakshminarayan i Reddy 2014). Longitudinalna istraživanja pokazuju da je internalni lokus povezan s manjom (van der Akker, Buntinx, Metsemakers, van der Aa i Knottnerus, 2001), a eksternalni lokus s većom učestalošću obolijevanja od višestrukih bolesti (van der Akker, Buntinx, Metsemakers i Knottnerus, 2000) te s akutnim i kroničnim tjelesnim simptomima (Van der Voort, Luis i Hamilton, 1997). Zanimljivo je da je u nekim istraživanjima lokus kontrole najbolji prediktor zdravstvenih ishoda, bolji i od biomedicinskih pokazatelja. Tako npr. internalnost najbolje predviđa objektivne indikatore zdravstvenog oporavka pet mjeseci nakon moždanog udara, pri čemu taj efekt nije posredovan niti strategijama suočavanja niti zdravstvenim ponašanjima. Iako je količina objašnjene varijance relativno mala, oko $10 \%$, ni jedna druga ispitivana varijabla ne objašnjava veću količinu varijance, čak ni neurološki indikatori težine bolesti (Johnston i sur., 1999).

Međutim, česti su i rezultati koji pokazuju da lokus kontrole nije povezan s objektivnim indikatorima zdravstvenih ishoda. Tako npr. istraživanja pokazuju da lokus kontrole nije povezan sa zdravstvenim stanjem starijih osoba (Perrig-Chiello i sur., 1999). Tijekom desetogodišnjeg praćenja osoba koje su doživjele infarkt miokarda lokus kontrole nije bio povezan s mortalitetom niti s ponovnim javljanjem infarkta (Welin, Lappas i Wilhelmsen, 2000), a isto vrijedi i za pacijente s karcinomom (De Boer, Ryckman, Pruyn i Van den Borne, 1999). Na osnovi lokusa kontrole ne može se predvidjeti incidencija karcinoma dojke (Price i sur., 2001), a kod dijabetičara ovisnih o inzulinu lokus kontrole nije bio povezan s razinom glukoze u krvi (Helgeson i Franzen, 1998).

Razlozi ovakvih nekonzistentnih rezultata su brojni, a među najznačajnijima su vrlo raznovrsne konceptualizacije samog konstrukta, kao i upotreba različitih mjernih instrumenata koji često imaju probleme s pouzdanošću i valjanošću. Zbog toga se može zaključiti da dosadašnja istraživanja govore o potencijalnoj važnosti lokusa kontrole za tjelesno zdravlje, međutim, veza između ove dimenzije ličnosti i tjelesnog zdravlja još se uvijek ne može smatrati dovoljno potvrđenom.

\section{MEHANIZMI POVEZANOSTI LOKUSA KONTROLE SA ZDRAVSTVENIM ISHODIMA}

\section{Lokus kontrole i kardiovaskularno funkcioniranje}

Brojna istraživanja pokazuju da su lokus kontrole i njemu srodni konstrukti povezani s kardiovaskularnom reaktivnošću, iz čega bi se moglo zaključiti da je to jedan od potencijalnih mehanizama djelovanja lokusa kontrole na zdravstvene ishode. Npr. Lawler i Schmied (1992) navode da je uz čvrstoću ličnosti internalni lokus 
kontrole također povezan s manjom kardiovaskularnom reaktivnošću izazvanom stresnim podražajem. Osim toga, viša razina stresa kod žena s eksternalnim lokusom i viši sistolički krvni tlak najbolje predviđaju čestinu obolijevanja u sljedećih godinu dana. Ispitivanja na djeci pokazuju da kod dječaka crne rase postoji najveća povezanost između niske internalnosti i višeg sistoličkog krvnog tlaka u odnosu na ostale kombinacije spola i rase (Wilson, Williams, Arheart, Bryant i Alpert, 1994). Dakle, ovi nalazi sugeriraju da internalni lokus kontrole vjerojatno može smanjiti simpatičkoadrenalnu aktivaciju i kardiovaskularnu reaktivnost. Sličan se zaključak može izvesti i iz istraživanja koja se bave efektima radne okoline na zdravstvene ishode, a koja nalaze veću učestalost infarkta miokarda, povećanog krvnog tlaka i ostalih kardiovaskularnih bolesti kod osoba čija su zanimanja istovremeno i vrlo zahtjevna i nekontrolabilna, kao što je to slučaj kod vozača kamiona ili radnika na tekućoj traci (Öhman i Bohlin, 1989). Važnost kontrole za kardiovaskularne bolesti može se vidjeti i iz modela koji opisuje odnos između psihosocijalne radne okoline i tjelesnih i mentalnih bolesti (Karasek, Baker, Marxer, Ahlbom i Theorell, 1981). Ovaj model pretpostavlja da se psihosocijalna radna okolina može opisati dvjema dimenzijama. Prvu dimenziju čine zahtjevi posla, odnosno frekvencija stresora, a drugu potencijalna kontrola stresora. Interakcija ove dvije dimenzije predviđa zdravstvene ishode i to tako da su visoki zahtjevi i niska mogućnost kontrole povezani s većom učestalošću zdravstvenih problema. Istraživanja zaista potvrđuju da su visoki stres i niska kontrola povezani ne samo s lošijim mentalnim zdravljem, nego i sa znakovima i simptomima kardiovaskularnih bolesti te s kardiovaskularnim mortalitetom (Parkes, 1991).

Međutim, laboratorijska istraživanja odnosa između percepcije kontrole i kardiovaskularne reaktivnosti ne daju uvijek jednoznačne rezultate. Naime, brojna istraživanja pokazuju da je kontrola averzivnih podražaja, pogotovo onda kada zahtijeva određeni napor povezana s uzorkom kardiovaskularnog reagiranja, koji, ako se podržava i ponavljano javlja može dovesti do povećanog krvnog tlaka i kardiovaskularnih bolesti (Öhman i Bohlin, 1989). Npr. u istraživanju koje su proveli Lawler, Schmied, Armstead i Lacy (1990), veća želja za kontrolom povezana je s većom kardiovaskularnom reaktivnošću pri rješavanju laboratorijskih zadataka, posebno kod ispitanika s A tipom ponašanja (Lawler i sur., 1990). Na temelju takvih nalaza autori čak pretpostavljaju da bi želja za kontrolom mogla biti komponenta koja žene s A tipom ponašanja čini sklonijima koronarnim bolestima. Sumirajući rezultate brojnih laboratorijskih istraživanja Öhman i Bohlin (1989) navode da do povećane kardiovaskularne reaktivnosti ne dovodi kontrola sama po sebi, već se prije čini da je nedostatak kontrole jedan od faktora koji dovodi do aktivnih suočavajućih napora, koji onda dovode i do povećane kardiovaskularne reaktivnosti. Istraživanja u kojima se ne koristi laboratorijska manipulacija kontrole nego generalizirane mjere lokusa kontrole također pokazuju da efekti lokusa kontrole na kardiovaskularnu reaktivnost mogu biti moderirani strategijama suočavanja. Tako npr. Mueller, Guenther, Habel i Rockstroh (1998) navode da osobe s internalnim lokusom koje se 
aktivno suočavaju pokazuju veću kardiovaskularnu reaktivnost nego osobe s internalnim lokusom koje se suočavaju pasivno. Dakle, čini se da efekti lokusa kontrole na kardiovaskularnu reaktivnost ovise o suočavajućim naporima, a vjerojatno i o vrsti stresne situacije. Osim toga, ljudi se razlikuju po svojim sposobnostima korištenja kontrole za efikasno suočavanje. Dok su neki sposobni koristiti kontrolu za efikasno suočavanje i tako smanjiti kardiovaskularni odgovor, drugi nemaju nužnih sposobnosti za suočavanje, što može dovesti do povećane kardiovaskularne reakcije čak i kada je situacija sama po sebi kontrolabilna. Takav nedostatak može rezultirati češćim i trajnijim stresnim epizodama i stoga može biti faktor koji osobu čini sklonijom povećanom krvnom tlaku i ostalim kardiovaskularnim bolestima.

\section{Lokus kontrole i imunološko funkcioniranje}

Drugi mehanizam putem kojeg lokus kontrole može djelovati na zdravlje je putem njegove povezanosti s imunološkim funkcioniranjem. Iako ni ovaj mehanizam nije dovoljno ispitan, postojeća istraživanja uglavnom pokazuju da internalni lokus ima pozitivne efekte na imunološko funkcioniranje, a eksternalni negativne.

Kao što je poznato, istraživanja izvedena i na ljudima i na životinjama uglavnom jednoznačno pokazuju lošije imunološko funkcioniranje pod djelovanjem stresnih događaja nad kojima nemamo kontrolu u usporedbi s kontrolabilnim stresnim događajima (Sieber i sur., 1991. Slični se nalazi dobivaju i u istraživanjima koja se izravno odnose na efekte lokusa kontrole na imunološko funkcioniranje. Npr. Reynaert i suradnici (1995) su kod depresivnih osoba ustanovili razlike u aktivnost stanica ubojica (NK stanica) s obzirom na lokus kontrole. Naime, osobe s eksternalnim lokusom imale su sniženu aktivnost NK stanica u odnosu na one s internalnim lokusom. Dakle, kod depresivnih osoba koje imaju narušeni stanični imunitet internalni lokus kontrole može imati zaštitnu funkciju u njegovu očuvanju.

\section{Lokus kontrole i zdravstvena ponašanja}

Jedna od temeljnih pretpostavki vezanih uz odnos lokusa kontrole i zdravstvenih ponašanja je da će osobe s internalnim lokusom biti sklonije manifestirati pozitivnija zdravstvena ponašanja nego osobe s eksternalnim lokusom. Internalni lokus se čak smatra jednim od najbitnijih faktora koji doprinosi razvoju odgovornosti za vlastito zdravlje. Iako su brojna istraživanja to i potvrdila, rezultati nisu uvijek u skladu s navedenom pretpostavkom. Osim toga, dobiveni su vrlo različiti rezultati ovisno o tome radi li se o zdravim ili bolesnim osobama. Zbog toga će najprije biti prikazani rezultati koji se odnose na zdrave osobe.

U pregledu ranijih istraživanja koja su koristila jednodimenzionalnu mjeru lokusa kontrole Strickland (1978) navodi da su preventivna zdravstvena ponašanja češća kod osoba s internalnim lokusom. Međutim, neka kasnija istraživanja nisu 
potvrdila ovaj nalaz (npr. Callaghan, 1998), dok su u drugima, koja su koristila višedimenzionalne mjere lokusa kontrole dobiveni složeniji odnosi. Tako BoothButterfield, Anderson i Booth-Butterfield (2000) navode da je pušenje kod adolescenata povezano s nižim internalnim i višim eksternalnim zdravstvenim lokusom kontrole (slučajnost, sudbina), ali i nižim eksternalnim lokusom kontrole koji se odnosi na moćne druge. Slični nekonzistentni rezultati dobiveni su i za ostala zdravstvena ponašanja, kao što su tjelesna aktivnost, zdrava prehrana, korištenje alkohola i dodataka prehrani (Steptoe i Wardle, 2001; Wulundari, Craig i Whelan, 2013). Ovakvi se rezultati najčešće objašnjavaju time što istraživači ne uzimaju u obzir vrijednost zdravlja za ispitanike. Naime, važan konstrukt u Rotterovoj teoriji je i vrijednost potkrepljenja budući da potencijal za ponašanje u određenoj situaciji ne ovisi samo o očekivanju potkrepljenja nego i o njegovoj vrijednosti. Vrijednost potkrepljenja Rotter shvaća kao stupanj preferencije prema nekom potkrepljenju ako je vjerojatnost svih potkrepljenja jednaka (Weiner, 1992). Iz toga slijedi da bi internalni lokus kontrole trebao biti snažnije povezan sa zdravstvenim ponašanjima kod onih pojedinaca koji zdravlje vrednuju visoko u odnosu na ostale životne ciljeve, što istraživanja uglavnom potvrđuju. Analizirajući velik broj različitih istraživanja Nemcek (1990) zaključuje da pojedinci koji visoko vrednuju zdravlje i koji imaju internalni lokus kontrole češće prihvaćaju preventivna zdravstvena ponašanja i prema njima imaju pozitivnije stavove, a Steptoe i Wardle (2001) nalaze da su povezanosti između internalnog lokusa i zdravstvenih ponašanja veće kod ispitanika koji više vrednuju vlastito zdravlje. Također, takve osobe češće koriste zdraviju prehranu (Bennett, Moore, Smith, Murphy i Smith, 1994; Elison i Ciftci, 2015), a žene s takvim uvjerenjima češće si same pregledavaju grudi (Lau, Hartman i Ware, 1986).

Steptoe i Wardle (2001) navode još neke razloge zbog kojih povezanosti između lokusa kontrole i zdravstvenih ponašanja mogu biti nekonzistentne ili uglavnom niske. Prvi se odnosi na konceptualizaciju mjera zdravstvenog lokusa kontrole. Tako se npr. internalni zdravstveni lokus kontrole može smatrati kombinacijom uvjerenja u osobnu kontrolu nad bolešću, njenom prevencijom, kompetencijom i samookrivljavanjem. Slučajnost kao komponenta eksternalnog zdravstvenog lokusa kontrole može odražavati ne samo uvjerenje da je naše zdravlje pod kontrolom sudbine, nego i uvjerenja o genetskim i okolinskim determinantama nad kojima pojedinac ima ograničenu kontrolu. Ove specifične komponente zdravstvenih lokusa kontrole mogu imati različite efekte na pojedina zdravstvena ponašanja, što može dovesti do smanjenja njihovih povezanosti s generalnijim dimenzijama lokusa kontrole. Tako su npr. Paxton i Sculthorpe (1999) našli da su teži pojedinci uvjereniji da je težina pod kontrolom i internalnih i eksternalnih faktora (izlaganje hrani i ohrabrivanje od strane drugih), ali ne i pod kontrolom genetskih faktora. Kada eksternalni i genetski faktori ne bi bili mjereni posebno nego kao jedinstvena dimenzija eksternalnog lokusa tjelesne težine, tada bi se efekt eksternalnih faktora na tjelesnu težinu smanjio ili izgubio. 
Drugi razlog odnosi se na upotrebu ili nedovoljno velikih uzoraka ispitanika, čime se smanjuje snaga statističkih testova, ili na korištenje velikih, ali heterogenih uzoraka u kojima ispitanici variraju s obzirom na dob, zdravstveni i socioekonomski status. Zdravstvena ponašanja određena su brojnim faktorima, od širokih kulturalnih, demografskih i ekonomskih utjecaja, preko individualnih kao što su dob, spol i zdravstveni status, do psiholoških kao što su uvjerenja i stavovi. Zbog djelovanja navedenih faktora $u$ heterogenim uzorcima efekti lokusa kontrole na zdravstvena ponašanja mogu biti prikriveni. Nadalje, zdravstvena ponašanja mogu varirati na različite načine, kao npr. jesu li zdravstveno štetna (npr. pušenje) ili korisna (npr. tjelesno vježbanje), manifestiraju li se primarno zbog zdravstvenih razloga (npr. pregledavanje grudi) ili zbog različitih i zdravstvenih i nezdravstvenih razloga (npr. konzumiranje alkohola), jesu li ili nisu zasićena kulturalnim faktorima (npr. navike prehrane) itd. (Lawton, Kapke i Gerdes, 2016; Steptoe i Wardle, 2001), što sve može djelovati na njihovu povezanost s drugim varijablama.

Uzimajući u obzir sve navedene nedostatke, Steptoe i Wardle (2001) nalaze da je internalni lokus kontrole uglavnom povezan s ponašanjima koja su korisna za zdravlje i koja se manifestiraju prvenstveno zbog zdravstvenih razloga. Eksternalni lokus kontrole (slučajnost) negativno je povezan sa zdravstveno korisnim oblicima ponašanja, a pozitivno s rizičnim zdravstvenim ponašanjima kao što su pušenje i korištenje alkohola. Komponenta eksternalnog lokusa kontrole koja se odnosi na moćne druge pozitivno je povezana i sa zdravstveno korisnim i sa zdravstveno štetnim oblicima ponašanja. Od zdravstveno korisnih oblika ponašanja ova je dimenzija povezana prvenstveno s onim ponašanjima koja su najčešće predmet upozorenja stručnjaka za javno zdravstvo ili propagandnih poruka, kao što su npr. smanjeno korištenje alkohola ili korištenje voća u prehrani. Međutim, ova dimenzija može biti povezana s lošijim zdravstvenim ponašanjima (npr. rjeđe peru zube i rjeđe se bave tjelesnim vježbanjem) onda kada osoba vjeruje da zdravstveni stručnjaci mogu riješiti probleme koji iz toga mogu proizaći.

Kada se radi o povezanosti lokusa kontrole i zdravstvenih ponašanja pacijenata, istraživanja upućuju na znatno veću važnost eksternalnog lokusa kontrole, posebno dimenzije koja se odnosi na moćne druge, odnosno liječnike i medicinsko osoblje. Ova je dimenzija vrlo često pozitivno povezana s različitim oblicima zdravstvenog ponašanja koje pacijentima savjetuju liječnici (npr. pohađanje fizioterapije, uzimanje vitamina) te općenito $s$ boljim pridržavanjem propisanih tretmana i liječničkih uputa (Myers i Myers, 1999). Također, ova je dimenzija lokusa kontrole povezana s traženjem medicinskog tretmana, pri čemu i sam tretman dovodi do povećanja ovog aspekta eksternalnog lokusa kontrole (Goldsteen, Counte i Goldsteen, 1994). Iako je ovakva povezanost korisna za održavanje medicinskog tretmana, problem je u tome što kontinuirano korištenje medicinskih usluga može kod pojedinca razviti uvjerenje da njegovo zdravlje nitko ne može kontrolirati, odnosno da je ono rezultat slučajnosti, sudbine ili sreće. To uvjerenje pak znatno smanjuje vjerojatnost budućeg kontakta s liječnicima. 
Dakle, iz dosadašnjih se istraživanja može zaključiti da je uvjerenje da je zdravlje pod našom kontrolom uglavnom povezano s preventivnim zdravstvenim ponašanjima, dok je uvjerenje da je naše zdravlje pod kontrolom moćnih drugih povezano s boljim pridržavanjem zdravstvenih tretmana. Međutim, važno je uočiti da lokus kontrole može prethoditi i biti posljedica zdravstvenih iskustava. Lokus kontrole i iskustva interaktivno mogu dovesti do nastanka ciklusa zdravstvenih ponašanja, koji mogu trajati određeno vrijeme i biti korisni u određenoj fazi, ali koji isto tako prethode novom ciklusu koji više ne mora biti adaptivan.

\section{Lokus kontrole i suočavanje}

Povezanost lokusa kontrole sa strategijama suočavanja proizlazi već iz osnovnih teorijskih pretpostavki transakcijskog modela suočavanja. Stupanj u kojem netko smatra da ima kontrolu nad događajima u svom životu u velikoj mjeri određuje razinu prijetnje koju izazivaju različite situacije, kao i procjenu vlastitih kapaciteta za rješavanje problema koji izazivaju stres (Lazarus i Folkman, 2004). Opće uvjerenje da imamo kontrolu nad životnim situacijama, kao i uvjerenje da kontroliramo neku specifičnu stresnu situaciju povezani su s intenzitetom i ustrajnošću suočavajućih odgovora. Empirijska evidencija uglavnom potvrđuje ove pretpostavke i općenito pokazuje da se osobe s internalnim lokusom kontrole efikasnije suočavaju sa stresnim situacijama nego pojedinci s eksternalnim lokusom.

Istraživanja na zdravim odraslim ispitanicima uglavnom pokazuju da je internalni lokus kontrole pozitivno povezan na problem usmjerenim suočavanjem, ali i s učestalim korištenjem ostalih načina suočavanja (Forsythe i Compas, 1987; Hoffman i Levy-Shiff, 1994; Park, Sacco i Edmondson, 2012), dok istraživanja na adolescentima pokazuju da je internalni lokus uglavnom povezan s aktivnim, na problem usmjerenim načinima suočavanja (Hoffman i Levy-Shiff, 1994), a eksternalni sa suočavanjem izbjegavanjem (Gomez, 1997). Kod pacijenata podvrgnutim kirurškim intervencijama eksternalni zdravstveni lokus kontrole (slučajnost) povezan je s pasivnim strategijama suočavanja (Sorlie i Sexton, 2001), a ista je situacija i kod osoba zaraženih HIV-om (Grassi, Righi, Sighinolfi, Makuoi i Ghinelli, 1998). Zbog visokih povezanosti internalnog i eksternalnog lokusa kontrole s pojedinim strategijama suočavanja, autori koji ispituju efekte suočavanja na izgaranje na poslu (npr. Bennett, Kelaher i Ross, 1994) navode da je internalni lokus zapravo sličan tzv. internalnim strategijama suočavanja, kao što su izražavanje emocija, strpljivost i uzimanje odmora, dok je eksternalni lokus sličan eksternalnim strategijama koje uključuju fatalističke stavove, negativna očekivanja i oslanjanje na sudbinu. Istraživanja uglavnom potvrđuju povezanost eksternalnog lokusa s eksternalnim strategijama suočavanja, međutim, osobe s internalnim lokusom ne oslanjaju se uvijek samo na internalne strategije suočavanja (Gueritault-Chalvin, Demi, Peterson i Kalichman, 2000). 
Navedeni su rezultati u skladu s pretpostavkom da osobe koje vjeruju da kontroliraju ishode vlastitog ponašanja u stresnim situacijama ulažu veće suočavajuće napore, posebno kroz učestalije korištenje na problem usmjerenih suočavanja. Istraživanja također pokazuju da je efikasnost suočavanja najveća onda kada postoji podudarnost između lokusa kontrole i načina suočavanja. Tako npr. osobe s internalnim lokusom koje koriste strategije suočavanja nepodudarne s uvjerenjem o kontroli ishoda, kao što su npr. strategije izbjegavanja, pokazuju manju razinu efikasnosti suočavanja, odnosno doživljavaju veću razinu stresa (Gomez, 1998). Zanimljivo je da izgleda da načini suočavanja majki mogu biti važni za razvoj lokusa kontrole njihove djece. Naime, djeca onih majki koje su više koristile problemu, a manje na emocije usmjerena suočavanja češće u adolescenciji imaju internalni lokus kontrole (Hoffman i Levy-Shiff, 1994).

Iako brojna istraživanja pokazuju da je lokus kontrole povezan sa strategijama suočavanja te da strategije suočavanja mogu posredovati efekte lokusa kontrole na doživljaj stresa i psihološku prilagodbu, još uvijek nedostaje adekvatna evidencija da strategije suočavanja posreduju i efekte lokusa kontrole na objektivne indikatore tjelesnog zdravlja. Ono što se na osnovi postojećih istraživanja može pretpostaviti i što zasigurno zahtijeva daljnja istraživanja jest da su efekti internalnog lokusa na zdravstvene ishode izravni, dok su efekti eksternalnog lokusa češće posredovani strategijama suočavanja (Gueritault-Chalvin i sur., 2000).

\section{NAJVAŽNIJI PROBLEMI U ISTRAŽIVANJIMA ODNOSA LOKUSA KONTROLE I ZDRAVSTVENIH ISHODA}

U budućim bi istraživanjima veću pažnju trebalo posvetiti i nekim drugim potencijalnim mehanizmima povezanosti lokusa kontrole sa zdravstvenim ishodima. Jedan od takvih mehanizama su negativne emocije, odnosno mentalno zdravlje. Naime, brojna istraživanja pokazuju da je eksternalni lokus kontrole povezan s depresivnošću i anksioznošću (Van der Voort i sur., 1997), a dobro je poznato da su dugotrajne negativne emocije povezane s nepoželjnim kardiovaskularnim, endokrinim i imnološkim odgovorima (Herbert i Cohen, 1993), što može rezultirati različitim bolestima.

Neki od najvažnijih problema vezanih uz lokus kontrole odnose se na njegovo mjerenje. Naime, još se uvijek najveći dio istraživanja temelji na unidimenzionalnim mjerama internalnog-eksternalnog lokusa kontrole, zanemarujući činjenicu da je lokus kontrole višedimenzionalni konstrukt. Posebno su zanemarene neke potencijalno važne komponente eksternalnog lokusa kontrole. Tako su npr. Wallston i suradnici (1999), polazeći od činjenice da najveći dio populacije čine vjernici, konstruirali skalu koja ispituje stupanj uvjerenosti da naše zdravlje kontrolira Bog (GLHC; The God Locus of Health Control). Početna ispitivanja na uzorcima bolesnika s reumatskim bolestima pokazuju da ova skala ima dobre metrijske karak- 
teristike te da je negativno povezana s pokazateljima psihosocijalne prilagodbe. U novije je vrijeme konstruirano više sličnih skala, a rezultati pokazuju da je vjerovanje da naše zdravlje kontrolira Bog povezano s nekim zdravstveno korisnim oblicima ponašanja kao što su manje korištenje alkohola i rjeđi rizični seksualni odnosi (Moore, 2014).

Osim za ispitanike sa specifičnim karakteristikama, specifične komponente lokusa kontrole mogu biti primjerene i kod određenih situacija. Kao što je već navedeno, u nepoznatim i nejasnim situacijama veća je uloga generaliziranih očekivanja, dok je u poznatim situacijama veća uloga specifičnih očekivanja koja proizlaze iz prošlih iskustava u tim situacijama. Iz toga slijedi da bi u poznatim situacijama (npr. kronična oboljenja) primjerenije bilo koristiti situacijski specifične mjere lokusa kontrole, a u novim i nejasnim situacijama (npr. infarkt miokarda) mjere generaliziranog lokusa kontrole. Dodatni problem sa specifičnim mjerama lokusa kontrole je u njihovoj nedovoljno poznatoj konstruktnoj valjanosti. Naime, te mjere vrlo često ne prolaze kroz ustanovljene postupke psihometrijske evaluacije, kao što je to slučaj s mjerama generaliziranog lokusa poput Rotterove I-E skale. Budući da već postoji preko 50 mjera lokusa kontrole, da su nam povezanosti između tih skala uglavnom nepoznate te da se lokus kontrole ponekad mjeri i skalama samoefikasnosti i atribucijskog stila, postoji velika nejasnoća oko toga koje skale i koliko dobro mjere originalni Rotterov koncept lokusa kontrole (Furnham, 2009).

Daljnji problem vezan uz lokus kontrole je prečesto naglašavanje dihotomije internalna spram eksternalne kontrole, a zanemarivanje mogućnosti dvojne kontrole, odnosno onih pojedinaca koji vjeruju da potkrepljenja kontroliraju i internalni i eksternalni faktori. Zbog toga što lakše mogu pronaći optimalnu ravnotežu između osobne odgovornosti i ograničenja okolinskih faktora, Marks (1998) pretpostavlja da se pojedinci s dvojnim lokusom efikasnije suočavaju sa stresnim situacijama i da su bolje prilagođeni nego pojedinci s kontrolom (internalni lokus) i pojedinci bez kontrole (eksternalni lokus). Ta je pretpostavka u skladu i s istraživanjima koja govore o većoj efikasnosti suočavanja onda kada postoji sukladnost između procjene kontrole i strategija suočavanja (Forsythe i Compas, 1987). Dakle, pojedinci s dvojnom kontrolom mogli bi imati znatnu prednost pri prilagođavanju svoje percepcije kontrole situacijskim zahtjevima, što im, s jedne strane, može omogućiti točniju procjenu vlastite kontrole nad situacijom, a, s druge strane, fleksibilnije suočavanje. Zbog toga bi buduća istraživanja svakako trebala ispitati moguće prednosti dvojne kontrole, a posebno njene efekte na zdravstvene ishode.

$\mathrm{S}$ dvojnom kontrolom povezan je i problem iluzije kontrole. Dobro je poznato da ljudi najčešće imaju nerealnu percepciju kontrole okolinskih događaja, odnosno da percipiraju da je njihova kontrola veća nego što zaista jest, da percipiraju povezanosti tamo gdje ih stvarno nema te da misle da mogu predviđati događaje u mjeri koja je daleko od realnosti (Presson i Benassi, 1996). Čini se da internalni lokus dijelom odražava takvu iluziju kontrole budući da je on više povezan s idealnim, a eksternalni lokus s realnim stupanjem kontrole događaja (Carton i Nowicki, 
1994). Dosadašnja istraživanja adaptivnih prednosti iluzije kontrole pokazuju nekonzistentne rezultate (Thompson, 1999), pa bi bilo vrijedno ispitati njene efekte na psihosocijalnu prilagodbu i kod osoba s dvojnim lokusom kontrole.

Treba napomenuti da lokus kontrole odražava i kulturalne vrijednosti i običaje te da eksternalni lokus kontrole unutar nekih kultura može biti adaptivniji nego internalni. Tako npr. Marks (1998) navodi razliku između primarne i sekundarne kontrole, pri čemu se primarna kontrola odnosi na stupanj utjecaja pojedinca na okolinu, a sekundarna na njegovu prilagodbu postojećoj realnosti. Sličnost primarne i sekundarne kontrole s internalnim i eksternalnim lokusom sasvim je očigledna, kao i činjenica da zapadna društva prvenstveno naglašavaju primarnu, a istočna sekundarnu kontrolu. Buduća bi istraživanja trebala ispitati vrijede li nalazi dobiveni u zapadnim, pretežno individualističkim kulturama i u kolektivističkim kulturama Istoka.

Na kraju, važan praktični problem je mogućnost promjene lokusa kontrole edukacijskim i/ili terapijskim intervencijama. Premda se često podrazumijeva da je jedan od glavnih ciljeva primjene skala lokusa kontrole identifikacija osoba čija uvjerenja mogu imati negativne zdravstvene posljedice pa stoga trebaju pomoć, gotovo da se ništa ne zna o tome može li se lokus kontrole mijenjati takvim intervencijama i kakva je njihova učinkovitost (Furnham, 2009).

\section{LITERATURA}

Alexander, D.A., Wells, A. (1991). Reactions of police officers to body handling after a major disaster: A before and after comparison. British Journal of Psychiatry 159, 517-555.

Andrykowski, M.A., Brady, M.J. (1994). Health locus of control and psychological distress in cancer patients: Interactive effects of context. Journal of Behavioral Medicine, 17, 439-458.

Baker, T.A., Buchanan, N.T., Corson, N. (2008). Factors influencing chronic pain intensity in older black women. Examining depression, locus of control, and physical health. Journal of Women's Health, 17, 869-878. DOI: 10.1089/jwh.2007.0452

Bandura, A. (1982). Self-efficacy mechanisms in human agency. American Psychologist, 37, 122-147.

Bennett, L., Kelaher, M., Ross, M. (1994). Quality of life in health care professionals: Burnout and its associated factors in HIV/AIDS related care. Psychology and Health: An International Journal, 9, 273-283.

Bennett, P., Moore, L., Smith, A., Murphy, S., Smith, S. (1994). Health locus of control and value of health as predictors of dietary behaviour. Psychology and Health, 10, 41-54.

Booth-Butterfield, M., Anderson, R.H., Booth-Butterfield, S. (2000). Adolescents' use of tobacco, health locus of control, and self-monitoring. Health Communication, 12, 137148.

Bosma, H., Schrijvers, C., Mackenbach, J.P. (1999). Socioeconomic inequalities in mortality and importance of perceived control: A cohort study. British Medical Journal, 319, 1469-1470. 
Brewin, C., Shapiro, D. (1984). Beyond locus of control: Attribution of responsibility for positive and negative outcomes. British Journal of Psychology, 15, 43-50.

Burish, T., Carey, M., Wallston, K., Stein, M., Jamison, R., Lyles, J. (1984). Healthy locus of control and chronic disease: An external orientation may be advantageous. Journal of Social and Clinical Psychology, 2, 326-332.

Burns, S.M., Mahalik, J.R. (2006). Physical health, self-reliance, and emotional control as moderators of the relationship between locus of control and mental health among men treated for prostate cancer. Journal of Behavioral Medicine, 29, 561-572. DOI: 10.1007/ s10865-006-9076-1

Callaghan, P. (1998). Social support and locus of control as correlates of UK nurses' healthrelated behaviours. Journal of Advanced Nursing, 28, 1127-1133. DOI: 10.1046/j.13652648.1998.00811.x

Carton, J.S., Nowicki, S. (1994). Antecedents of individual differences in locus of control of reinforcement: A critical review. Genetic, Social and General Psychology Monographs, $120,33-81$.

Carver, C.S., Scheier, M.F. (1981). Attention and self-regulation: A control theory approach to human behavior. New York: Springer-Verlag.

Chambers, C., Katic, M., Chiu, S., Redelmeier, D.A., Levinson, W., Kiss, A., Hwang, S.W. (2013). Predictors of medical or surgical and psychiatric hospitalization among a population-based cohort of homeless adults. American Journal of Public Health, 103, 380388.

Christensen, A.J., Turner, C.S., Smith, T.W., Holman, J.M., Gregory, M.C. (1991). Health locus of control and depression in end-stage renal disease. Journal of Consulting and Clinical Psychology, 59, 419-424.

Dalgard, O.S., Lund Håheim, L. (1998). Psychosocial risk factors and mortality: A prospective study with special focus on social support, social participation, and locus of control in Norway. Journal of Epidemiology and Community Health, 52, 476-481.

De Boer, M.F., Ryckman, R.M., Pruyn, J.F.A., Van den Borne, H.W. (1999). Psychosocial correlates of cancer relapse and survival: A literature review. Patient Education and Counseling, 37, 215-230. DOI: 10.1016/S0738-3991(99)00029-4

Elison, Z.M., Ciftci, A. (2015). Digesting antifat attitudes: Locus of control and social dominance orientation. Translational Issues in Psychological Science, 1, 262-270. DOI: $10.1037 /$ tps0000029

Folkman, S. (1984). Personal control and stress and coping processes: A theoretical analysis. Journal of Personality and Social Psychology, 46, 839-852.

Forsythe, C.J., Compas, B.E. (1987). Interaction of cognitive appraisal of stressful events and coping: Testing the goodness of fit hypothesis. Cognitive Therapy and Research, $11,473-485$.

Fowers, B. (1994). Perceived control, illness status, stress, and adjustment to cardiac illness. Journal of Psychology, 128, 567-576. DOI: 10.1080/00223980.1994.9914914

Frazier, P.A., Schauben, L. (1994). Causal attributions and recovery from rape and other stressful life events. Journal of Social and Clinical Psychology, 13, 1-14. DOI: 10.1521/ jscp.1994.13.1.1 
Furnham, A. (2009). Locus of control and attribution style. U: M.R. Leary, R.H. Hoyle (ur.), Handbook of individual differences in social behavior (str. 274-287). New York: The Guilford Press.

Furnham, A., Steele, H. (1993). Measuring locus of control: A critique of general, children's, health- and work-related locus of control questionnaires. British Journal of Psychology, 84, 443-479. DOI: 10.1111/j.2044-8295.1993.tb02495.x

Goldsteen, R.L., Counte, M.A., Goldsteen, K. (1994). Examining the relationship between health locus of control and the use of medical care services. Journal of Aging and Health, 6, 314-335. DOI: 10.1177/089826439400600303

Gomez, R. (1997). Locus of control and Type A behavior pattern as predictors of coping styles among adolescents. Personality and Individual Differences, 23, 391-398.

Gomez, R. (1998). Locus of control and avoidant coping: Direct, interactional and mediational effects on maladjustment in adolescents. Personality and Individual Differences, 24, 325-334.

Grassi, L., Righi, R., Sighinolfi, R., Makoui, S., Ghinelli, F. (1998). Coping styles and psychosocial-related variables in HIV-infected patients. Psychosomatics, 39, 350-359. DOI: 10.1016/S0033-3182(98)71323-4

Gueritault-Chalvin, V., Demi, A., Peterson, J.L., Kalichman, S.C. (2000). Work-related stress and occupational burnout in AIDS caregivers: Test of a coping model with nurses providing AIDS care. AIDS Care, 12, 149-161. DOI: 10.1080/09540120050001823

Hamdan-Mansour, A.M., Marmash, L.R., Alayyan, R., Hyarat, S.Y. (2014). Difference in perception between nurses and patients related to patients' health locus of control. International Journal of Nursing Practice, 20, 242-249. DOI: 10.1111/ijn.12132

Haslam, C., Lawrence, W. (2004) Health-related behavior and beliefs of pregnant smokers. Health Psychology, 23, 486-491. DOI: 10.1037/0278-6133.23.5.486

Helgeson, V.S., Franzen, P.L. (1998). The role of perceived control in adjustment to diabetes. Anxiety, Stress and Coping, 11, 113-136. DOI: 10.1080/10615809808248308

Herbert, T.B., Cohen, S. (1993). Depression and immunity: A meta-analytic review. Psychological Bulletin, 113, 472-487.

Hoffman, M.A., Levy-Shiff, R. (1994). Coping and locus of control: Cross-generational transmission between mothers and adolescents. Journal of Early Adolescence, 14, 391405. DOI: $10.1177 / 0272431694014003005$

Hoffmann, A., Pfiffner, D., Hornung, R., Niederhauser, H. (1995). Psychosocial factors predict medical outcome following a first myocardial infarction. Coronary Artery Disease, 6, 147-152.

Hudek-Knežević, J., Kardum, I. (2009). Five-factor personality dimensions and 3 healthrelated personality constructs as predictors of health. Croatian Medical Journal, 50, 394-402. DOI: $10.3325 / \mathrm{cmj} .2009 .50 .394$

Johnston, M., Morrison, V., MacWalter, R., Patridge, C. (1999). Perceived control, coping, and recovery from disability following stroke. Psychology and Health, 14, 181-192. DOI: $10.1080 / 08870449908407322$

Karasek, R., Baker, D., Marxer, F., Ahlbom, A., Theorell, T. (1981). Job decision latitude, job demands, and cardiovascular disease: A prospective study of Swedish men. American Journal of Public Health, 71, 694-705. 
Kardum, I., Hudek-Knežević, J. (2009). Konceptualni i metodološki problemi u ispitivanjima odnosa ličnosti i tjelesnog zdravlja. Društvena istraživanja, 18, 3-24.

Kardum, I., Hudek-Knežević, J. (2012). Relationships between five-factor personality traits and specific health-related personality dimensions. International Journal of Clinical and Health Psychology, 12, 373-387.

Kardum, I., Hudek-Knežević, J. (2012a). Osjećaj koherentnosti i tjelesno zdravlje. Psihologijske teme, 21, 249-271.

Kardum, I., Hudek-Knežević, J., Krapić, N. (2016). Efekti i mehanizmi djelovanja čvrstoće ličnosti na zdravlje. Psihologijske teme, 25, 499-517.

Kendell, K., Saxby, B., Farrow, M., Naisby, C. (2001). Psychological factors associated with short-term recovery from total knee replacement. British Journal of Health Psychology, 6, 41-52. DOI: 10.1348/135910701169043

Kiviruusu, O., Huurre, T., Haukkala, A., Aro, H. (2013). Changes in psychological resource moderate the effect of socioeconomic status on distress symptoms: A 10-year follow-up among young adults. Health Psychology, 32, 627-636. DOI: 10.1037/a0029291

Kobasa, S.C. (1982). Commitment and coping in stress resistance among lawyers. Journal of Personality and Social Psychology, 42, 168-177.

Koestner, R., McClelland, D.C. (1990). Perspectives on competence motivation. U: L.A. Pervin (ur.), Handbook of personality: Theory and research (str. 527-548). New York: The Guilford Press.

Krause, J.S., Stanwyck, C.A., Maides, J. (1998). Locus of control and life adjustment: Relationship among people with spinal cord injury. Rehabilitation Counseling Bulletin, 41, 162-172.

Lau, R.R., Hartman, K.A., Ware, J.E. (1986). Health as a value: Methodological and theoretical considerations. Health Psychology, 5, 25-43.

Lawler, K.A., Schmied, L.A. (1992). A prospective study of women's health: The effects of stress, hardiness, locus of control, Type A behavior, and physiological reactivity. Women and Health, 19, 27-41. DOI: 10.1300/J013v19n01_02

Lawler, K.A., Schmied, L.A., Armstead, C.A., Lacy, J.E. (1990). Type A behavior, desire for control, and cardiovascular reactivity in young adult women. Journal of Social Behavior and Personality, 5, 135-158.

Lawton, K.E., Kapke, T.L., Gerdes, A.C. (2016). Understanding parental locus of control in Latino parents: Examination of cultural influences and help-seeking intentions for childhood ADHD. Cultural Diversity and Ethnic Minority Psychology, 22, 288-298. DOI: $10.1037 / \mathrm{cdp} 0000022$

Lazarus, R.S., Folkman, S. (2004). Stres, procjena i suočavanje. Jastrebarsko: Naklada Slap.

Levenson, H. (1974). Activism and powerful other: Distinctions within the concept of internal-external locus of control. Journal of Personality Assessment, 38, 377-383.

Marks, L.I. (1998). Deconstructing locus of control: Implications for practitioners. Journal of Counseling and Development, 76, 251-260.

Moore, E.W. (2014). Assessing God locus of control as a factor in college students' alcohol use and sexual behavior. Journal of American College Health, 62, 578-587. DOI: $10.1080 / 07448481.2014 .947994$ 
Mueller, M.M., Guenther, A., Habel, I., Rockstroh, B. (1998). Active coping and internal locus of control produces prolonged cardiovascular reactivity in young men. Journal of Psychophysiology, 12, 29-39.

Myers, L.B., Myers, F. (1999). The relationship between control beliefs and self-reported adherence in adults with cystic fibrosis. Psychology, Health and Medicine, 4, 387-391. DOI: $10.1080 / 135485099106135$

Nemcek, M.A. (1990). Health beliefs and preventive behaviour: A review of research literature. American Association of Occupational Health Journal, 38, 127-138.

O’Hea, E.L., Moon, S., Grothe, K.B., Boudreaux, E., Bodenlos, J.S., Wallston, K., Brantley, P. (2009). The interaction of locus of control, self-efficacy, and outcome expectancy in relation to $\mathrm{HbA1c}$ in medically underserved individuals with type 2 diabetes. Journal of Behavioral Medicine, 32, 106-117. DOI: 10.1007/s10865-008-9188-x

Öhman, A., Bohlin, G. (1989). The role of controllability in cardiovascular activation and cardiovascular disease: Help or hindrance? U: A. Steptoe, A. Appels (ur.), Stress, personal control and health (str. 257-276). Chichester: Wiley.

Park, C.L., Sacco., S.J., Edmondson, D. (2012). Expanding coping goodness-of-fit: religious coping, health locus of control, and depressed affect in heart failure patients. Anxiety, Stress, \& Coping, 25, 137-153. DOI: 10.1080/10615806.2011.586030

Parkes, K.R. (1989). Personal control in an occupational context. U: A. Steptoe, A. Appels (ur.), Stress, personal control and health (str. 21-47). Chichester: Wiley.

Parkes, K.R. (1991). Locus of control as moderator: An explanation for additive versus interactive findings in the demand-discretion model of work stress? British Journal of Psychology, 82, 291-312.

Paxton, S.J., Sculthorpe, A. (1999). Weight and health locus of control beliefs in an Australian community sample. Psychology and Health, 14, 417-431. DOI: 10.1080/08870449908407338

Perrig-Chiello, P., Perrig, W.J., Stähelin, H.B. (1999). Health control beliefs in old age: Relationship with subjective and objective health, and health behaviour. Psychology, Health and Medicine, 4, 83-94. DOI: 10.1080/135485099106423

Poll, I.B., Kaplan De-Nour, A. (1980). Locus of control and adjustment to chronic hemodialysis. Psychological Medicine, 10, 153-157.

Potdar, S., Lakshminarayan, N., Reddy, S.G. (2014). Relationship of locus of control with plaque and gingival status before and after oral health education in a group of college students: An experimental study. International Journal of Dental Hygiene, 13, 42-48. DOI: $10.1111 /$ idh.12093

Presson, P.K., Benassi, V.A. (1996). Illusion of control: A meta-analytic review. Journal of Social Behavior and Personality, 11, 493-510.

Price, M.A., Tennant, C.C., Smith, R.C., Butow, P.N., Kennedy, S.J., Kossoff, M.B., Dunn, S.M. (2001). The role of psychosocial factors in the development of breast carcinoma: Part I - The cancer prone personality. Cancer, 91, 679-685.

Reeh, H.E., Bryan, H., Cairns, K. (1998). Adolescent health: The relationships between health locus of control, beliefs and behaviours. Guidance and Counseling, 13, 23-29.

Reynaert, C., Janne, P., Bosly, A., Staquet, P., Zdanowicz, N., Vause, M., Chatelain, B. (1995). From health locus of control to immune control: Internal locus of control has 
a buffering effect on natural killer cell activity decrease in major depression. Acta Psychiatrica Scandinavica, 92, 294-300.

Roddenberry, A., Renk, K. (2010). Locus of control and self-efficacy: Potential mediators of stress, illness, and utilization of health services in college students. Child Psychiatry and Human Development, 41, 353-370. DOI: 10.1007/s10578-010-0173-6

Rodin, J., Langer, E.J. (1977). Long-term effects of a control-relevant intervention with the institutionalized aged. Journal of Personality and Social Psychology, 35, 897-902.

Rotter, J.B. (1990). Internal versus external control of reinforcement. American Psychologist, 45, 489-493.

Shelly, M., Pakenham, K. (2007). The effects of preoperative preparation on postoperative outcomes: The moderating role of control appraisal. Health Psychology, 26, 183-191.

Shelly, M., Pakenham, K. (2007). The effects of preoperative preparation on postoperative outcomes: The moderating role of control appraisal. Health Psychology, 26, 183-191.

Sieber, W.J., Rodin, J., Larson, L., Ortega, S., Cummings, N., Levy, S., Whiteside, T., Herberman, R. (1992). Modulation of human natural killer cell activity by exposure to uncontrollable stress. Brain, Behavior and Immunity, 6, 141-156.

Siman-Tov, A., Kaniel, S. (2011). Stress and personal resource as predictors of the adjustment of parents to autistic children: A multivariate model. Journal of Autism and Developmental Disorders, 41, 879-890. DOI: 10.1007/s10803-010-1112-X

Simoni, J.M., Ng, M.T. (2002). Abuse, health locus of control, and perceived health among HIV-positive women. Health Psychology, 21, 89-93.

Sorlie, T., Sexton, H.C. (2001). Predictors of the process of coping in surgical patients. Personality and Individual Differences, 30, 947-960. DOI: 10.1016/S01918869(00)00085-4

Steptoe, A., Wardle, J. (2001). Locus of control and health behaviour revisited: A multivariate analysis of young adults from 18 countries. British Journal of Psychology, 92, 659-672.

Stevens, N.R., Hamilton, N.A., Wallston, K.A. (2011). Validation of the Multidimensional health locus of control scales for labor and delivery. Research in Nursing \& Health, 34, 282-296. DOI: 10.1002/nur.20446

Strickland, B.R. (1978). Internal-external expectancies and health-related behaviors. Journal of Consulting and Clinical Psychology, 46, 1192-1211.

Syme, S.L. (1989). Control and health: A personal perspective. U: A. Steptoe, A. Appels (ur.), Stress, personal control and health (str. 3-18). Chichester: Wiley.

Taylor, S.E. (1983). Adjustment to threatening events: A theory of cognitive adaptation. American Psychologist, 38, 1161-1173.

Thompson, S.C. (1999). Illusions of control: How we overestimate our personal influence. Current Directions in Psychological Science, 8, 187-190.

van den Akker, M., Buntinx, F., Metsemakers, J.F.M., Knottnerus, J.A. (2000). Marginal impact of psychosocial factors on multimorbidity: Results of an explorative nested case-control study. Social Science and Medicine, 50, 1679-1693. DOI: 10.1016/S02779536(99)00408-6

van den Akker, M., Buntinx, F., Metsemakers, J.F.M., van der Aa, M., Knottnerus, J.A. (2001). Psychosocial patient characteristics and GP-registered chronic morbidity: A 
prospective study. Journal of Psychosomatic Research, 50, 95-102. DOI: 10.1016/ S0022-3999(00)00227-0

Van der Voort, D.J., Luis, P.K., Hamilton, S.E. (1997). Some correlates of health locus of control among multicultural individuals. Current Psychology, 16, 167-178.

Wallston, K. (1989). Assessment of control in health-care settings. U: A. Steptoe, A. Appels (ur.), Stress, personal control and health (str. 85-106). Chichester: Wiley.

Wallston, K., Wallston, B., DeVellis, R. (1978). Development of the multidimensional health locus of control (MHLS) scales. Health Education Monographs, 6, 160-169.

Wallston, K.A., Malcarne, V.L., Flores, L., Hansdottir, I., Smith, C.A., Stein, M.J., Weisman, M.H., Clements, P.J. (1999). Does God determine your health? The God Locus of Health Control Scale. Cognitive Therapy and Research, 23, 131-142.

Weiner, B. (1992). Human motivation: Metaphors, theories, and research. Newbury Park, CA: Sage Publications.

Welin, C., Lappas, G., Wilhelmsen, L. (2000). Independent importance of psychosocial factors for prognosis after myocardial infarction. Journal of Internal Medicine, 247, 629-639. DOI: 10.1046/j.1365-2796.2000.00694.x

Wilson, D.K., Williams, Z.L., Arheart, K., Bryant, E.S., Alpert, B.S. (1994). Race and sex differences in health locus of control beliefs and cardiovascular reactivity. Journal of Pediatric Psychology, 19, 769-778.

Wulundari, L.P.L., Craig, P., Whelan, A.K. (2013). Foetal health locus of control and iron supplementation adherence among pregnant women in Bali. Journal of Reproductive and Infant Psychology, 31, 94-101.

\title{
LOCUS OF CONTROL AND PHYSICAL HEALTH
}

\begin{abstract}
The effects of the locus of control on physical health as well as the basic mechanisms through which it exerts its effects are reviewed in the present article. Theoretical bases of the locus of control, its measurement and its relationships to similar psychological constructs, especially various aspects of perceived control, are described in the first part of the article. Further, the most important empirical results on the effects of the locus of control on physical health are shown. Four primary mechanisms through which the locus of control may affect physical health are proposed - through its effects on cardiovascular and immunological functioning as well as health behaviors and coping with stress. Finally, the most relevant theoretical and methodological problems characteristic of the research on the relationship between the locus of control and physical health are reported.
\end{abstract}

Key words: locus of control, health locus of control, physical health, health behavior, coping 